\title{
Chemical and Geochemical Characterization of the Evolution of Soils of Krakatau Islands
}

\author{
Dian Fiantis ${ }^{1}$, Frisa Ginting ${ }^{1}$, Gusnidar Gusnidar ${ }^{1}$, Malik Nelson ${ }^{2}$, E. VanRanst ${ }^{3}$, and \\ Budiman Minasny ${ }^{4}$ \\ ${ }^{1}$ Universitas Andalas \\ ${ }^{2}$ State Agricultural Polytechnic Payakumbuh \\ ${ }^{3}$ Universiteit Gent \\ ${ }^{4}$ University of Sydney - Camperdown and Darlington Campus Burkitt-Ford Library
}

July 31,2020

\begin{abstract}
The Krakatau volcano erupted in 1883 and created a unique ecosystem where the surrounding islands were completely sterilised. While volcanic activity and plant succession have been extensively studied in the Krakatau islands, the soils received less attention. As the age of the parent material is known precisely, and the islands are isolated, soils of Krakatau islands could provide insights on the first stages of weathering in tropical volcanic regions. This study aims to characterize soils from the Krakatau islands. In 2015, ten sampling sites were selected from Mt. Anak Krakatau, Rakata, Panjang, and Sebesi islands, all making part of the Krakatau island complex. Field morphology was observed from representative profiles on each island. Soil samples were collected and analysed for physical and chemical properties. The geochemical analysis was carried out using the X-ray fluorescence (XRF). Linear discriminant analysis was used to separate materials from the four islands based on their chemical and geochemical concentrations. While the four islands were nearby and influenced by the 1883 eruption of Mt. Krakatau, the analysis showed that the chemical and geochemical characteristics of volcanic ash for each island are distinct. Discriminant analysis of chemical and geochemical properties differentiated soils of Anak Krakatau as the youngest ones, and soils of Sebesi are the most developed ones. The following sequence of the soil weathering degree was established: Sebesi $>$ Rakata > Panjang > Anak Krakatau.
\end{abstract}

Keywords: Volcanic soils; andosols; geochemistry; discriminant analysis; tephra; Indonesia INTRODUCTION

The late Mt. Krakatau erupted in May-August 1883 and had sterilised all soil and vegetation in the islands. Much has been investigated on the vegetation and volcanic activities of Krakatau (R. J. Whittaker, Bush, \& Richards, 1989); however, the soils of Krakatau are less studied. As the age of the parent material is known precisely, and the area is less influenced by human activities, examining soils of Krakatau could provide an insight into the first stages of weathering and pedogenesis in tropical volcanic regions. The study of volcanic materials and their weathering products can inform us on the nutrient supply, and impacts on existing soils (Alloway, Andreastuti, Setiawan, Miksic, \& Hua, 2017; Anda, 2016; Dian Fiantis, Ginting, Nelson, \& Minasny, 2019). Understanding the triggers and controls of soil formation will lead to better sustainable use and made us aware of the fragility of soil formation and avoid degradation.

\section{MATERIALS AND METHODS}

Soil sampling and analysis 
During a survey conducted in April 2015 ten representative soil profiles were selected: 1 soil profile on Mt. Anak Krakatau (elevation $60 \mathrm{~m}$ a.s.l), 2 soil profiles on Rakata (elevation 2 and $50 \mathrm{~m}$ a.s.l), 2 soil profiles on Panjang (elevation 2 and $48 \mathrm{~m}$ a.s.l) and 5 soil profiles on Sebesi islands (elevation 66, 156, 250, 356, and 455 $m$ a.s.l). The location of the samplings is given in Figure 1. As the Anak Krakatau, Rakata, and Panjang islands do not have roads and a national park, sampling was done in the best possible manner to select a typical representative soil in the area. At Anak Krakatau, loose materials covered the entire island, and thus only 1 profile was be excavated. At Rakata and Panjang islands, the soils are loose sandy materials, and thus one profile near the coast and one at a higher elevation were excavated. Sebesi island is more developed with vegetation, and therefore the sampling locations represent a transect of elevation.

The soil morphological features were observed from soil profiles in the field, and soils were sampled by collecting approximately $3 \mathrm{~kg}$ from each soil horizon and transferred into polyethylene plastic bags for analyses. Undisturbed soil samples were obtained using a standard ring sampler with a known volume to determine soil bulk density. The samples were then brought to the laboratory, air-dried, ground homogenously, and sieved to a size fraction smaller than $2 \mathrm{~mm}$.

The particle sizes of ash and soil samples were determined by sieving and pipette method (Staff, 1996). Siltand clay-sized fractions were measured after sedimentation, according to Stokes law. Soil pH was measured in $\mathrm{H}_{2} \mathrm{O}$ and $1 \mathrm{M} \mathrm{KCl}$ at a solution ratio of 1:5 after $30 \mathrm{~min}$ of equilibration. The Walkley and Black wet oxidation method was used to determine organic $\mathrm{C}$ content, and total $\mathrm{N}$ was determined by the Kjeldahl method (Tan, 2005). The available phosphate anion was analyzed colorimetrically using a visible-light spectrophotometer (Tan, 2005). P retention was determined following the method described by Blakemore, Searle, and Daly (1987). Exchangeable cations and cation exchange capacity (CEC) were determined by $1 \mathrm{~N} \mathrm{NH}_{4} \mathrm{OAc}, \mathrm{pH}$ 7.0, extraction; the leachate was used to determine the exchangeable base cations, which were measured by atomic absorption spectrophotometry (AAS). Saturation of individual base cations was calculated by dividing the content of individual exchangeable cations by the effective CEC and expressed as a percentage (Anda, 2012). Extraction with acid ammonium oxalate for the dissolution of non-crystalline materials and metal-organic complexes was carried out as outlined by Van Reeuwijk (2002). Contents of acid-ammonium oxalate-extractable $\mathrm{Si}, \mathrm{Al}$, and $\mathrm{Fe}\left(\mathrm{Si}_{\mathrm{o}}, \mathrm{Al}_{\mathrm{o}}\right.$, and $\left.\mathrm{Fe}_{\mathrm{o}}\right)$ were measured by AAS.

The elemental composition of the samples was determined using a benchtop X-ray fluorescent spectrometer (XRF) PANalytical Epsilon 3, with 120-second readings with three replicates.

\section{References}

Alloway, B. V., Andreastuti, S., Setiawan, R., Miksic, J., \& Hua, Q. (2017). Archaeological implications of a widespread 13th Century tephra marker across the central Indonesian Archipelago. Quaternary Science Reviews, 155 , 86-99.

Anda, M. (2012). Cation imbalance and heavy metal content of seven Indonesian soils as affected by elemental compositions of parent rocks. Geoderma, 189 , 388-396.

Anda, M. (2016). Characteristics of pristine volcanic materials: Beneficial and harmful effects and their management for restoration of agroecosystem. Science of the total environment, 543 , 480-492.

Bani, P., Normier, A., Bacri, C., Allard, P., Gunawan, H., Hendrasto, M., \& Tsanev, V. (2015). First measurement of the volcanic gas output from Anak Krakatau, Indonesia. Journal of Volcanology and Geothermal Research, 302 , 237-241.

Bétard, F. (2012). Spatial variations of soil weathering processes in a tropical mountain environment: the Baturité massif and its piedmont (Ceará, NE Brazil). Catena, 93 , 18-28.

Bey, A. (2003). Evapoclimatonomy modelling of four restoration stages following Krakatau's 1883 destruction. Ecological modelling, 169 (2-3), 327-337. 
Blakemore, L., Searle, P., \& Daly, B. (1987). Methods for chemical analysis of soils. New Zealand Soil Bureau Scientific, Report 80.New Zealand, Lower Hutt: New Zealand Society of Soil Science, p103 .

Camus, G., Gourgaud, A., \& Vincent, P. (1987). Petrologic evolution of Krakatau (Indonesia): implications for a future activity. Journal of Volcanology and Geothermal Research, 33 (4), 299-316.

Carey, S., Sigurdsson, H., Mandeville, C., \& Bronto, S. (1996). Pyroclastic flows and surges over water: an example from the 1883 Krakatau eruption. Bulletin of Volcanology, 57 (7), 493-511.

Carey, S., Sigurdsson, H., Mandeville, C., \& Bronto, S. (2000). Volcanic hazards from pyroclastic flow discharge into the sea: examples from the 1883 eruption of Krakatau, Indonesia. GEOLOGICAL SOCIETY OF AMERICA, 1-14.

Dahren, B., Troll, V. R., Andersson, U. B., Chadwick, J. P., Gardner, M. F., Jaxybulatov, K., \& Koulakov, I. (2012). Magma plumbing beneath Anak Krakatau volcano, Indonesia: evidence for multiple magma storage regions. Contributions to Mineralogy and Petrology, 163 (4), 631-651.

Decker, R. W., \& Hadikusumo, D. (1961). Results of the 1960 expedition to Krakatau. Journal of Geophysical Research, 66 (10), 3497-3511.

Deplus, C., Bonvalot, S., Dahrin, D., Diament, M., Harjono, H., \& Dubois, J. (1995). Inner structure of the Krakatau volcanic complex (Indonesia) from gravity and bathymetry data. Journal of Volcanology and Geothermal Research, 64 (1-2), 23-52.

Dörries, M. (2003). Global science: the eruption of Krakatau.Endeavour, 27 (3), 113-116.

Ernst, A. (1908). The new flora of the volcanic island of Krakatau : University Press.

Fiantis, D., Ginting, F. I., Nelson, M., \& Minasny, B. (2019). Volcanic Ash, Insecurity for the People but Securing Fertile Soil for the Future.Sustainability, 11 (11), 3072.

Fiantis, D., Nelson, M., Shamshuddin, J., Goh, T., \& Van Ranst, E. (2010). Determination of the geochemical weathering indices and trace elements content of new volcanic ash deposits from Mt. Talang (West Sumatra) Indonesia. Eurasian Soil Science, 43 (13), 1477-1485.

Fiantis, D., Nelson, M., Shamshuddin, J., Goh, T. B., \& Ranst, E. V. (2016). Initial carbon storage in new tephra layers of Mt. Talang in Sumatra as affected by pioneer plants. Communications in Soil Science and Plant Analysis, 47 (15), 1792-1812.

Hardjowigeno, S. (1992). The development and nature of soils on Rakata.GeoJournal, 28 (2), 131-138.

Hoffman-Rothe, A., Ibs-von Seht, M., Knieß, R., Faber, E., Klinge, K., Reichert, C., . . . Patria, C. (2006). Monitoring Anak Krakatau Volcano in Indonesia. Transactions American Geophysical Union, 87 (51), 581-586.

Keys, D. (2000). Catastrophe: an investigation into the origins of the modern world: Ballantine Books.

Kronberg, B., \& Nesbitt, H. (1981). Quantification of weathering, soil geochemistry and soil fertility. Journal of Soil Science, 32 (3), 453-459.

Köppen, W. (1936). Das Geographische System der Climate .

Mandeville, C. W., Carey, S., \& Sigurdsson, H. (1996). Magma mixing, fractional crystallization and volatile degassing during the 1883 eruption of Krakatau volcano, Indonesia. Journal of Volcanology and Geothermal Research, 74 (3-4), 243-274.

Ninkovich, D. (1979). Distribution, age and chemical composition of tephra layers in deep-sea sediments off western Indonesia. Journal of Volcanology and Geothermal Research, 5 (1-2), 67-86.

Nishimura, S., Nishida, J. i., Yokoyama, T., \& Hehuwat, F. (1986). Neo-tectonics of the Strait of Sunda, Indonesia. Journal of Southeast Asian earth sciences, 1 (2), 81-91. 
Parfitt, R. (1989). Optimum conditions for extraction of Al, Fe, and $\mathrm{Si}$ from soils with acid oxalate. Communications in Soil Science and Plant Analysis, 20 (7-8), 801-816.

Partomihardjo, T., Mirmanto, E., \& Whittaker, R. (1992). Anak Krakatau's Vegetation and Flora circa 1991, with Observations on a Decade of Development and Change. GeoJournal, 28 (2), 233-248.

Ruxton, B. P. (1968). Measures of the degree of chemical weathering of rocks. The Journal of Geology, 76 (5), 518-527.

Schlesinger, W. H., Bruijnzeel, L., Bush, M. B., Klein, E. M., Mace, K. A., Raikes, J. A., \& Whittaker, R. (1998). The biogeochemistry of phosphorus after the first century of soil development on Rakata Island, Krakatau, Indonesia. Biogeochemistry, 40 (1), 37-55.

Self, S. (1992). Krakatau revisited: the course of events and interpretation of the 1883 eruption. GeoJournal, 28 (2), 109-121.

Shinagawa, A., Miyauchi, N., \& Higashi, T. (1992). Cumulic soils on Rakata, Sertung and Panjang (Krakatau Is.) and properties of each solum. GeoJournal, 28 (2), 139-151.

Shinagawa, A., MIYAUCHI, N., \& HIGASII, T. (1986). The soils on the Krakatau Islands. Mem. Fac. Agr. Kagoshima Univ, 22, 131-155.

Sigurdsson, H., Carey, S., Mandeville, C., \& Bronto, S. (1991). Pyroclastic flows of the 1883 Krakatau eruption. Transactions American Geophysical Union, 72 (36), 377-381.

Špičák, A., Kozák, J., Vaněk, J., \& Hanuš, V. (2008). The Krakatau volcano 125 years after the catastrophic eruption (August 27, 1883).Studia Geophysica et Geodaetica, 52 (3), 449-454.

Staff, S. S. (1996). Soil survey laboratory methods manual. Soil Survey Investigations Rep. 42, Version 2.0 , 693-1036.

Stockmann, U., Cattle, S., Minasny, B., \& McBratney, A. B. (2016). Utilizing portable X-ray fluorescence spectrometry for in-field investigation of pedogenesis. Catena, 139 , 220-231.

Tan, K. H. (2005). Soil sampling, preparation, and analysis : CRC press.

Thornton, I. (2007). Island colonization: the origin and development of island communities : Cambridge University Press.

Thornton, I. W. (1997). Krakatau: the destruction and reassembly of an island ecosystem : Harvard University Press.

Thornton, I. W., Runciman, D., Cook, S., Lumsden, L. F., Partomihardjo, T., Schedvid, N. K., . . . Ward, S. A. (2002). How important were stepping stones in the colonization of Krakatau? Biological Journal of the Linnean Society, 77 (3), 275-317.

Van Bemmelen, R. W. (1970). The Geology of Indonesia (Vol. 1): Martinus Nijhoff.

Van Reeuwijk, L. (2002). Procedures for soil analysis (6th Edition ed.). Wageningen: International soil reference information Centre

Walter, T. R., Haghighi, M. H., Schneider, F. M., Coppola, D., Motagh, M., Saul, J., . . . Tilmann, F. (2019). Complex hazard cascade culminating in the Anak Krakatau sector collapse. Nature communications, $10(1), 1-11$.

Webster, R. (1977). Quantitative and numerical methods in soil classification and survey .

Whelley, P. L., Newhall, C. G., \& Bradley, K. E. (2015). The frequency of explosive volcanic eruptions in Southeast Asia. Bulletin of Volcanology, 77 (1), 1. 
Whittaker, R., Walden, J., \& Hill, J. (1992). Post-1883 ash fall on Panjang and Sertung and its ecological impact. GeoJournal, 28 (2), 153-171.

Whittaker, R. J., Bush, M. B., \& Richards, K. (1989). Plant Recolonization and Vegetation Succession on the Krakatau Islands, Indonesia. Ecological Monographs, 59 (2), 59-123. doi:10.2307/2937282

Zen, M. (1970). Growth and state of Anak Krakatau in September 1968.Bulletin Volcanologique, 34 (1), 205-215.

\section{FIGURES}

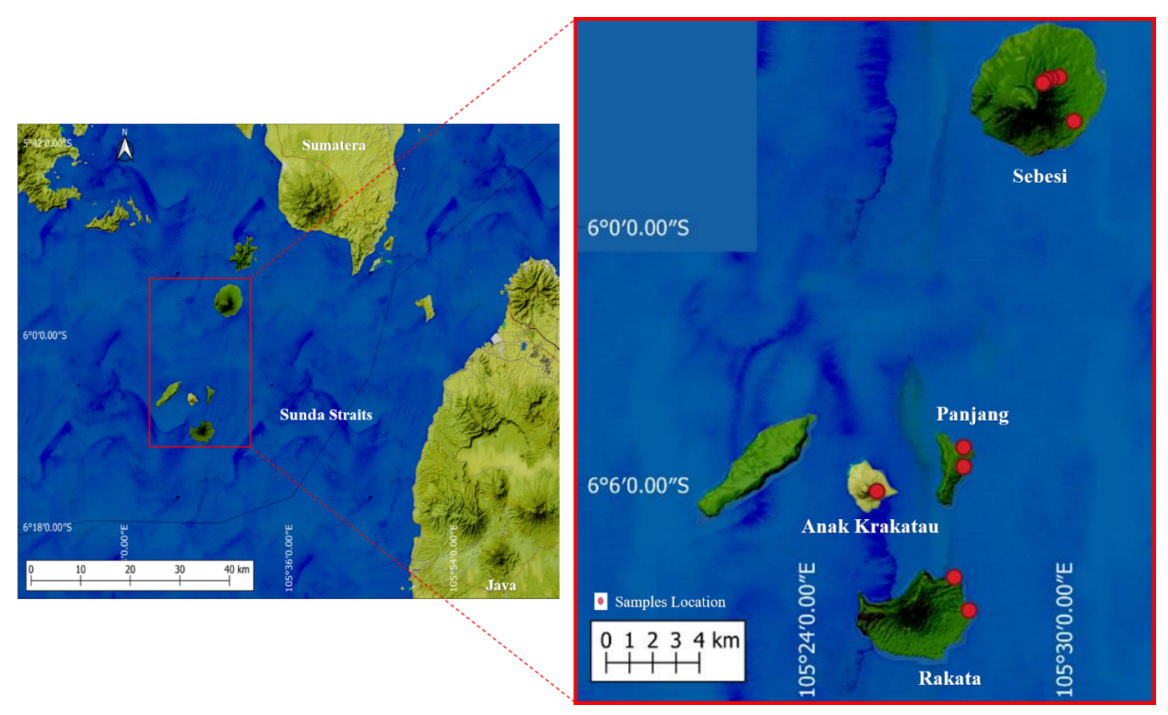

Figure 1. Location of field observations at the Krakatau islands.
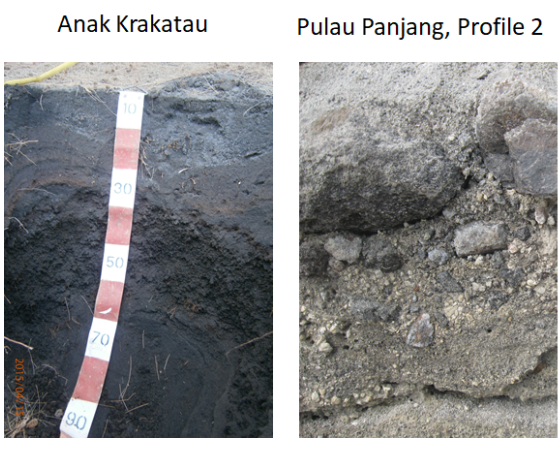

Rakata, Profile 2

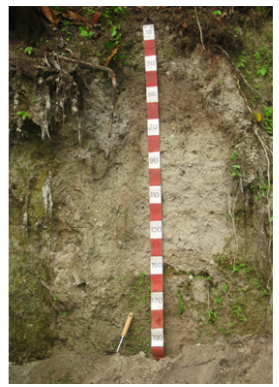

Sebesi, Profile 2

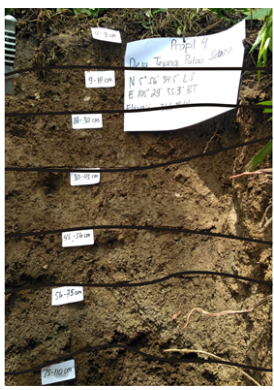

Figure 2. Photographs of soils of Krakatau islands. 


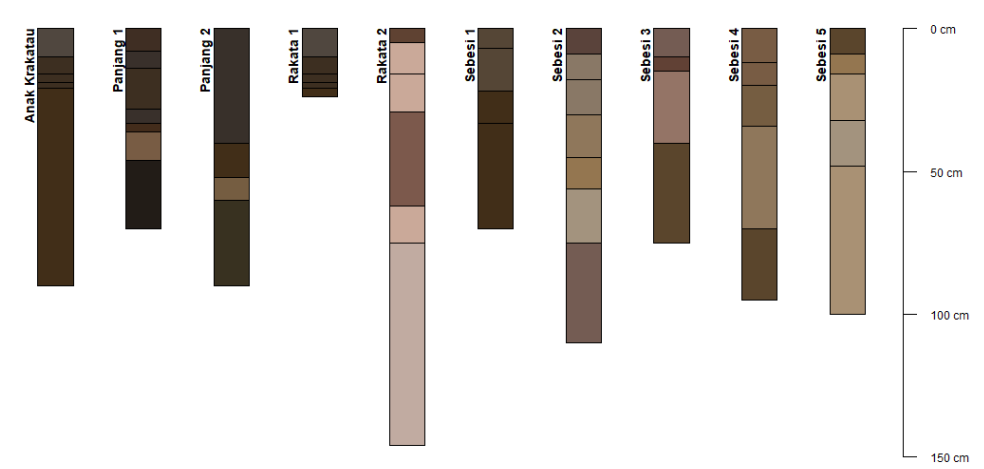

Figure 3. The morphological representation of Krakatau soils.

\section{Ternary Plot}

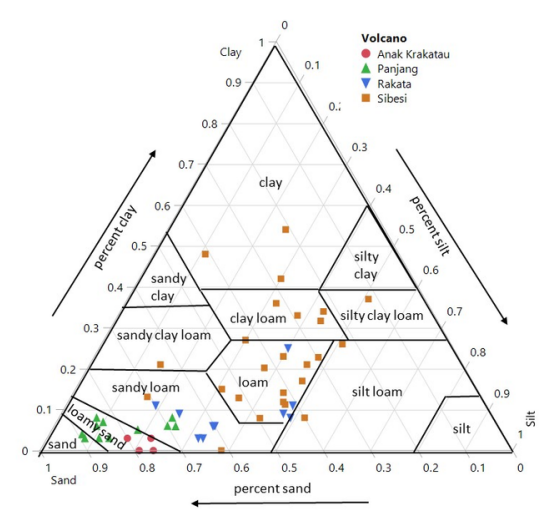

